\title{
Effect of dietary oridonin supplementation on growth performance, gut health, and immune response of broilers infected with Salmonella pullorum
}

\author{
Qiu Jue Wu ${ }^{1,2,3}$, Xiao Chuan Zheng ${ }^{3}$, Tian Wang ${ }^{3}$ and Tie Ying Zhang ${ }^{1 *}$
}

\begin{abstract}
Background: The effects of dietary supplementation of oridonin (ORI) on growth performance, cecal microbiota, epithelium development and antioxidant and immune parameters of broilers infected with S. pullorum were studied. A total of 300 1-d-old male chicks were selected and divided into 5 trial groups (6 replicates of 10 chickens): 1) nonchallenge control chicks (CON), 2) chicks treated with Salmonella Challenged Control (SCC), 3) chicks treated with S. pullorum challenge and $50 \mathrm{mg} / \mathrm{kg}$ ORI $(\mathrm{O} 1)$, 4) chicks treated with S. pullorum challenge and

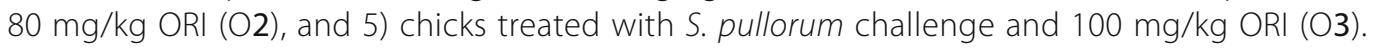

Results: The results showed that S. pullorum had no effect on the feed intake (FI), body weight gain (BWG) or feed conversion ratio (FCR) of broilers compared with the values measured for the CON group $(P>0.05)$. However, compared with the characteristics of CON, S. pullorum showed effects on the counts of Salmonella and Lactobacillus at 7 $\mathrm{d}$ and at $14 \mathrm{~d}(P<0.05)$, on jejunal development at $7 \mathrm{~d}(P<0.05)$, and on jejunal immunoglobulin $\mathrm{A}$ (IgA) concentration at $7 \mathrm{~d}(P<0.05)$. The addition of $100 \mathrm{mg} / \mathrm{kg}$ ORI had the greatest effect on the counts of Lactobacillus and Salmonella in cecal content $(P<0.05)$, malonaldehyde $(\mathrm{MDA})$ content in the jejunum $(P<0.05)$, villi height of the small intestine, and IgA concentrations in the jejunum $(P<0.05)$.

Conclusions: The results suggest that ORI can improve Salmonella-induced immune responses and protect intestinal health, not only through its immune inhibitory properties but also through its multi-protective effects on gut health.

Keywords: Broilers, Gut morphology, Immune, Intestinal microbiota, Oridonin

\section{Background}

S. pullorum is a capnophilic gram-negative rod-shaped bacterium that can cause pullorum disease (PD). Pullorum disease was once enzootic in many areas of the world [1]. Broiler chickens are known to be extremely sensitive to $S$. pullorum infections in the first $7 \mathrm{~d}$ of their life because of delayed development and establishment of their normal intestinal flora. S. pullorum infection can cause nutritional (protein, amino acid, and vitamin) deficiency, intestinal flora disorder, reduction in production performance, and invasion of internal organs in young

\footnotetext{
*Correspondence: myhuang1012@163.com

${ }^{1}$ State Key Laboratory of Animal Nutrition, Institute of Animal Sciences of Chinese Academy of Agricultural Sciences, NO.2, Yuan Ming Yuan West Road, HaiDian District, Beijing 100193, People's Republic of China

Full list of author information is available at the end of the article
}

birds, resulting in significant economic losses to the poultry industry [2]. Therefore, several synthetic chemicals (such as zinc-bearing clinoptilolite) have been used to control or limit the intestinal colonization and invasion of S. pullorum in poultry production [3].

Isodon rubescens (Donglingcao in Chinese) is widely used in traditional Chinese medicine and has long served as a popular medicine for respiratory and gastrointestinal bacterial infections, inflammation, and cancer [4]. Oridonin (ORI) is claimed to be a valid natural compound and one of the richest ent-kaurane diterpenoids of Isodon rubescens. ORI has generated much interest because of its notable pharmacological and biological activities, such as its anti-bacterial and anti-inflammatory properties and its ability to control viral replication, 
eliminate active oxygen radicals, and protect other internal organs, among other abilities [5]. Substantial research efforts have shown that isolated oridonin is used alone or in combination with other drugs to prevent and cure bacterial infection in vivo and in vitro, and since 1976, oridonin has been known to exhibit antimicrobial activity against gram-positive bacteria [6]. However, to the best of our knowledge, few studies have focused on the effects of dietary supplementation of oridonin or derivatives on antimicrobial activity against $S$. pullorum in animals, with no study addressing broiler chickens. Hence, the aims of this work were to evaluate the beneficial effects of oridonin supplementation on the growth performance, intestinal microbiota, and gut morphology of broiler chickens and to validate whether dietary oridonin supplementation could attenuate damage to the intestinal lining and protect broilers from negative effects of S. pullorum.

\section{Methods}

\section{Bird husbandry and experimental diets}

Three hundred 1-d-old male Arbor Acres (AA) broilers were obtained and divided into five dietary treatments, each with six replicates, 10 chickens per replicate, for a 21-d feeding trial. The 5 treatments were as follows: 1) nonchallenge control chicks (CON), 2) chicks treated with Salmonella Challenged Control (SCC), 3) chicks treated with $S$. pullorum challenge and $50 \mathrm{mg} / \mathrm{kg}$ ORI $(\mathrm{O} 1), 4)$ chicks treated with $S$. pullorum challenge and $80 \mathrm{mg} / \mathrm{kg}$ ORI (O2), and 5) chicks treated with S. pullorum challenge and $100 \mathrm{mg} / \mathrm{kg}$ ORI (O3). All birds were raised in multi-tiered brooder cages and kept in an environmentally controlled room. During the study period, birds had ad libitum access to water and a balanced unmedicated diet meeting or exceeding the recommendations of the National Research Council (NRC, 1994). The basal (starter) diets were based on corn and soybean meal, as shown in Table 1, and provided as a mash. The experimental design and procedures were approved by the Institutional Animal Care and Use Committee of Nanjing Agricultural University.

ORI used in the experiment was purchased from the Laieryin Biological Technology Company Limited (Luoyang, Henan province, P. R. China) with a purity of $98 \%$.

\section{Salmonella infection model}

The strain of S. pullorum (CVCC 533) was obtained from the China Veterinary Culture Collection Center (Beijing, P. R. China). Broilers in the SCC, O1, O2, and O3 experimental groups were orally treated with $4 \times$ $10^{4}$ CFU S. pullorum bacteria per bird on d 3 posthatch, and the chicks of the CON group were treated with an equal volume of physiological saline.
Table 1 Ingredients and nutrient composition of the basal diet (g/kg diet as-fed basis)

\begin{tabular}{ll}
\hline Ingredients (g/kg) & $1-21 \mathrm{~d}$ \\
Corn & 578 \\
Soybean meal (43\%, crude protein) & 325 \\
Corn gluten meal & 30 \\
Soybean oil & 27 \\
Limestone & 9.5 \\
Dicalcium phosphate & 17.5 \\
Salt & 3 \\
Choline chloride & 3.0 \\
Minerals premix & \\
Vitamin premix & \\
L-Lysine HCl & 2.5 \\
Methionine & 0.5 \\
Total & 2.5 \\
Calculation of nutrients (g/kg) ${ }^{3}$ & 1.5 \\
Apparent metabolizable energy (MJ/kg) & 1000 \\
Crude protein & \\
Calcium & 12.5 \\
Available Phosphorus & 212 \\
Lysine & 9.7 \\
Methionine & 4.2 \\
Methionine+cysteine & 10.8 \\
\hline
\end{tabular}

Note: ${ }^{1}$ Minerals premix provided the following per $\mathrm{kg}$ of diet: Fe (ferrous sulfate), $80 \mathrm{mg}$; Cu (copper sulfate), $8 \mathrm{mg} ; \mathrm{Mn}$ (manganese sulfate), $110 \mathrm{mg} ; \mathrm{Zn}$ (Bacitracin Zn), $65 \mathrm{mg}$; iodine (calcium iodate), $1.1 \mathrm{mg}$; Se (sodium selenite), $0.3 \mathrm{mg}$

${ }^{2}$ Vitamin premix provided the following per $\mathrm{kg}$ of diet: vitamin A (transretinyl acetate), 10,000 IU; vitamin $\mathrm{D}_{3}$ (cholecalciferol), $3000 \mathrm{IU}$; vitamin $\mathrm{E}$ (all-rac- $a$ tocopherolacetate), $30 \mathrm{IU}$; menadione, $1.3 \mathrm{mg}$; thiamine $2.2 \mathrm{mg}$; riboflavin, $8 \mathrm{mg}$; nicotinamide, $40 \mathrm{mg}$. pyridoxine. $\mathrm{HCl}, 4 \mathrm{mg}$; biotin, $0.04 \mathrm{mg}$; folic acid, $1 \mathrm{mg}$; vitamin $\mathrm{B}_{12}$ (cobalamine), $0.013 \mathrm{mg}$

${ }^{3}$ The nutrient levels were on an as-feed basis

\section{Sample collection and procedures}

Four, 11, and 18 days after S. pullorum infection, one chick per replicate was selected at random, weighed after a 12-h feed restriction, and sent to the Veterinary Laboratory for a bacterial culture of the cecal contents. Subsequently, the broilers were euthanized by cervical dislocation, and an approximately 2-cm-long section of the proximal jejunum was extracted, washed, and fixed for histological examination. The proximal jejunal mucosa was excised carefully, frozen, and kept for further analysis.

\section{Growth performance}

Body weight was measured at $1,7,14$, and $21 \mathrm{~d}$ of age. The amounts of feed supplied and feed waste were also weighed to calculate the feed intake (FI) and feed conversion ratio (FCR). Mortalities were recorded daily to calibrate growth performance parameters. 


\section{Intestinal microbial populations}

Approximately $1 \mathrm{~g}$ of mixed cecal content was diluted and homogenized. The homogenized suspension was serially diluted in PBS. The samples from the caeca were diluted to $10^{-1}, 10^{-2}, 10^{-3}, 10^{-4}$, and $10^{-5}$. From each dilution, $0.1 \mathrm{ml}$ was inoculated on agar plates for aerobics. The dilutions were plated on culture medium. The population of Lactobacilli was counted on MRS agar (pH 5.4, Huankai Microbial SCI. and Tech, Co., Ltd. Guangdong, China) after $48 \mathrm{~h}$ at $37^{\circ} \mathrm{C}$. The population of Salmonella was incubated and counted on bismuth sulfite agar (Qingdao Hope Bio-Technology Co. Ltd., Qingdao, P. R. China) incubated at $37{ }^{\circ} \mathrm{C}$ for $24 \mathrm{~h}$. The number of colony forming units (CFU) was expressed as a logarithmic $\left(\log _{10}\right)$ values per gram of intestinal digesta.

\section{Intestinal histomorphology}

Three jejunum cross-sections were prepared using standard paraffin embedding procedures by sectioning at a thickness of $5 \mu \mathrm{m}$ and staining with hematoxylin and eosin. The jejunum villus height and crypt depth of the stained sections were examined with an Axioplan-2 optical microscope (Carl Zeiss Jena $\mathrm{GmbH}$, Jena, Germany) coupled with a refrigerated QImaging Retiga 4000R digital camera (QImaging, Surrey, British Columbia, Canada) with a charge-coupled device detector, and were expressed in micrometers $(\mu \mathrm{m})$. A total of 15 complete, well-oriented crypt-villus units were measured with an image processing and analysis system (Version 1, Leica Imaging Systems Co., Ltd., Cambridge, UK) for each type of tissue from each broiler.

\section{Mucosal antioxidant and immunity index}

Approximately $0.3 \mathrm{~g}$ of intestinal mucosa samples was homogenized and centrifuged. The supernatant was used for examining mucosal antioxidant and immunity indices. Total superoxide dismutase (T-SOD) activity and malonaldehyde (MDA) content were measured using diagnostic kits (Nanjing Jiancheng Bioengineering Institute, Nanjing, Jiangsu, P.R. China). The levels of immunoglobulin G (IgG) were examined using a commercially available 125 I radioimmunoassay kit with goat anti-chicken IgG (BlueGene, Shanghai, People's Republic of China). The assay was responsive to a test limit of $0.1 \mathrm{~g} / \mathrm{mL}$. The concentration of intestinal immunoglobulin A (IgA, BlueGene, Shanghai, People's Republic of China) was determined based on the method described by a chicken IgA enzyme-linked immunosorbent assay.

\section{Statistical analysis}

An analysis of variance was performed using the General Linear Model procedure of the Statistical Package for Social Sciences 20.0 (SPSS Inc., Chicago, IL, USA) in a completely randomized design. The differences among all the treatment means were identified using the Tukey's range test at levels of significance $P \leq 0.05$.

\section{Results}

Growth performance and microbial population

Neither S. pullorum infection nor ORI supplementation had an effect on FI, BWG, FCR or mortality (Table 2).

Throughout the evolution of the infection, Salmonella reduced the population of Lactobacillus at 7 and $14 \mathrm{~d}$ and promoted the growth of Salmonella colonies in challenged chickens compared with that of the control group $(P<0.05)$ (Table 3$)$. However, ORI supplementation increased the counts of Lactobacillus (with the exception of $\mathrm{O} 1$ and $\mathrm{O} 2$, at $21 \mathrm{~d}$ ) and reduced the Salmonella population (excluding the O1 group, at $21 \mathrm{~d}$ ) $(P<0.05)$ compared with that of the non-supplemented SCC group.

\section{Intestinal histomorphology}

The SCC group challenged by S. pullorum showed a decreased jejunal villus height and $\mathrm{V} / \mathrm{C}$ value $(P<0.05)$ and an increased jejunal crypt depth at $7 \mathrm{~d}(P<0.05)$ compared with those of the CON group (Table 4). ORI supplementation increased the villus height of chickens at all inclusion levels, increased $\mathrm{V} / \mathrm{C}$, and decreased crypt depth at $100 \mathrm{mg} / \mathrm{kg}$ compared with the values measured for the SCC group $(P<0.05)$. However, the

Table 2 Effect of oridonin on growth performance of broilers challenged with S. pullorum

\begin{tabular}{|c|c|c|c|c|c|c|c|}
\hline \multirow[t]{2}{*}{ Items } & \multicolumn{5}{|l|}{ Diet $^{b}$} & \multirow[t]{2}{*}{ SEM $^{c}$} & \multirow{2}{*}{$\begin{array}{l}P \text { - } \\
\text { value }\end{array}$} \\
\hline & CON & $\mathrm{SCC}$ & $\mathrm{O} 1$ & $\mathrm{O} 2$ & $\mathrm{O} 3$ & & \\
\hline \multicolumn{8}{|l|}{ BWG $^{a}, g /$ bird } \\
\hline d 1 to 7 & 95.5 & 94.8 & 96.7 & 104.1 & 110.6 & 2.02 & 0.578 \\
\hline d 8 to 14 & 189.4 & 178.8 & 192.1 & 195.4 & 196.4 & 2.48 & 0.297 \\
\hline d 15 to 21 & 336.2 & 334.8 & 338.7 & 342.7 & 342.9 & 2.20 & 0.948 \\
\hline \multicolumn{8}{|l|}{$\mathrm{Fl}^{\mathrm{a}}, \mathrm{g} / \mathrm{bird}$} \\
\hline d 1 to 7 & 113.2 & 114.7 & 108.3 & 114.5 & 119.5 & 2.75 & 0.767 \\
\hline d 8 to 14 & 276.5 & 273.5 & 278.6 & 277.4 & 276.9 & 7.23 & 0.998 \\
\hline d 15 to 21 & 556.5 & 572.6 & 548.6 & 552.3 & 552.2 & 7.23 & 0.768 \\
\hline \multicolumn{8}{|c|}{$\mathrm{FCR}^{\mathrm{a}}$, g feed intake/g weight gain } \\
\hline d 1 to 7 & 1.19 & 1.21 & 1.12 & 1.10 & 1.08 & 0.03 & 0.878 \\
\hline d 8 to 14 & 1.46 & 1.55 & 1.45 & 1.42 & 1.41 & 0.05 & 0.908 \\
\hline d 15 to 21 & 1.65 & 1.71 & 1.62 & 1.61 & 1.61 & 0.03 & 0.815 \\
\hline \multicolumn{8}{|l|}{ Mortality, \% } \\
\hline d 1 to 21 & 1.14 & 4.57 & 2.03 & 1.49 & 1.28 & 1.05 & 0.583 \\
\hline \multicolumn{8}{|c|}{$\begin{array}{l}{ }^{\mathrm{a}} \mathrm{BWG}=\text { Body weight gain; } \mathrm{FI}=\text { feed intake; } \mathrm{FCR}=\text { feed conversion ratio } \\
\text { b } \mathrm{CON}=\text { nonchallenge control, } \mathrm{SCC}=\text { Salmonella-challenged control, } \mathrm{O} 1=\mathrm{S} \text {. } \\
\text { pullorum challenge fed the basal diet plus } 50 \mathrm{mg} / \mathrm{kg} \mathrm{ORI} ; \mathrm{O} 2=\mathrm{S} \text {. pullorum } \\
\text { challenge fed the basal diet plus } 80 \mathrm{mg} / \mathrm{kg} \mathrm{ORI}, \mathrm{O} 3=\mathrm{S} \text {. pullorum challenge fed } \\
\text { the basal diet plus } 100 \mathrm{mg} / \mathrm{kg} \mathrm{ORI} \\
{ }^{\mathrm{c}} \mathrm{SEM}=\text { standard error of mean }\end{array}$} \\
\hline
\end{tabular}


Table 3 Effect of oridonin on cecal microbiota of broilers challenged with S. pullorum (log CFU)

\begin{tabular}{|c|c|c|c|c|c|c|c|}
\hline \multirow[t]{2}{*}{ Items } & \multicolumn{5}{|l|}{ Diet } & \multirow[t]{2}{*}{$\mathrm{SEM}^{2}$} & \multirow{2}{*}{$\begin{array}{l}P- \\
\text { value }\end{array}$} \\
\hline & $\mathrm{CON}$ & SCC & O1 & $\mathrm{O} 2$ & $\mathrm{O} 3$ & & \\
\hline \multicolumn{8}{|l|}{ Day 7} \\
\hline Lactobacillus & $7.34^{\mathrm{a}}$ & $5.94^{c}$ & $6.59^{b}$ & $6.97^{\mathrm{ab}}$ & $7.40^{\mathrm{a}}$ & 0.13 & 0.00 \\
\hline Salmonella & $7.13^{b}$ & $8.24^{\mathrm{a}}$ & $7.16^{b}$ & $7.13^{b}$ & $6.94^{b}$ & 0.11 & \\
\hline \multicolumn{8}{|l|}{ Day 14} \\
\hline Lactobacillus & $7.41^{\mathrm{a}}$ & $6.76^{\mathrm{b}}$ & $7.59^{\mathrm{a}}$ & $7.73^{\mathrm{a}}$ & $7.82^{\mathrm{a}}$ & 0.11 & \\
\hline Salmonella & $5.64^{c}$ & $7.57^{\mathrm{a}}$ & $6.37^{b}$ & $5.72^{\mathrm{C}}$ & $5.27^{c}$ & 0.17 & \\
\hline \multicolumn{8}{|l|}{ Day 21} \\
\hline Lactobacillus & $6.91^{b}$ & $6.76^{\mathrm{b}}$ & $6.83^{b}$ & $7.12^{\mathrm{ab}}$ & $7.39^{\mathrm{a}}$ & 0.06 & \\
\hline Salmonella & $6.76^{\mathrm{b}}$ & $7.67^{\mathrm{a}}$ & $7.13^{\mathrm{ab}}$ & $6.69^{b}$ & $6.32^{\mathrm{b}}$ & 0.12 & \\
\hline \multicolumn{8}{|c|}{$\begin{array}{l}{ }^{1} \mathrm{CON}=\text { nonchallenge control, } \mathrm{SCC}=\text { Salmonella-challenged control, } \mathrm{O} 1=\mathrm{S} \text {. } \\
\text { pullorum challenge fed the basal diet plus } 50 \mathrm{mg} / \mathrm{kg} \text { ORl; } \mathrm{O} 2=\mathrm{S} \text {. pullorum } \\
\text { challenge fed the basal diet plus } 80 \mathrm{mg} / \mathrm{kg} \mathrm{ORI}, \mathrm{O}=\mathrm{S} \text {. pullorum challenge } \mathrm{f} \\
\text { the basal diet plus } 100 \mathrm{mg} / \mathrm{kg} \mathrm{ORI} \\
{ }^{2} \mathrm{SEM}=\text { standard error of mean } \\
3, \mathrm{a}, \mathrm{b}, \mathrm{C} \text { Values within a row not sharing the same superscript are different at }\end{array}$} \\
\hline
\end{tabular}

villus height, crypt depth, and $\mathrm{V} / \mathrm{C}$ value in the intestinal mucosa of the broilers at $14 \mathrm{~d}$ or $21 \mathrm{~d}$ did not differ among groups.

\section{Antioxidant index}

The MDA content in SCC was increased at $21 \mathrm{~d}(P<0.05)$ compared with that of CON (Table 5). Moreover, the addition of ORI reduced the MDA content in the jejunal

Table 4 Effect of oridonin on the height of villi and crypt depth $(\mu \mathrm{m})$ in the jejunum of broilers challenged with S. pullorum

\begin{tabular}{|c|c|c|c|c|c|c|c|}
\hline \multirow[t]{2}{*}{ Items } & \multicolumn{5}{|l|}{ Diet } & \multirow[t]{2}{*}{$\mathrm{SEM}^{3}$} & \multirow{2}{*}{$\begin{array}{l}P- \\
\text { value }\end{array}$} \\
\hline & $\mathrm{CON}$ & SCC & $\mathrm{O} 1$ & $\mathrm{O} 2$ & $\mathrm{O} 3$ & & \\
\hline \multicolumn{8}{|l|}{ Day 7} \\
\hline Villus height & $1312^{a}$ & $1173^{b}$ & $1326^{a}$ & $1329^{a}$ & $1333^{a}$ & 17.56 & 0.007 \\
\hline Crypt depth & $245^{b}$ & $294^{a}$ & $285^{\mathrm{ab}}$ & $272^{a b}$ & $248^{b}$ & 5.78 & 0.004 \\
\hline $\mathrm{V} / \mathrm{C}^{1}$ & $5.36^{\mathrm{a}}$ & $4.00^{b}$ & $4.65^{\mathrm{ab}}$ & $4.89^{\mathrm{ab}}$ & $5.38^{\mathrm{a}}$ & 0.74 & 0.026 \\
\hline \multicolumn{8}{|l|}{ Day 14} \\
\hline Villus height & 1228 & 1185 & 1314 & 1357 & 1362 & 23.55 & 0.449 \\
\hline Crypt depth & 241 & 245 & 242 & 232 & 229 & 8.67 & 0.984 \\
\hline $\mathrm{V} / \mathrm{C}^{1}$ & 5.10 & 4.84 & 5.43 & 5.85 & 5.95 & 0.24 & 0.619 \\
\hline \multicolumn{8}{|l|}{ Day 21} \\
\hline Villus height & 1464 & 1314 & 1396 & 1439 & 1461 & 45.59 & 0.744 \\
\hline Crypt depth & 191 & 194 & 193 & 190 & 192 & 5.16 & 0.984 \\
\hline $\mathrm{V} / \mathrm{C}^{1}$ & 7.66 & 6.78 & 7.22 & 7.57 & 7.63 & 0.27 & 0.185 \\
\hline
\end{tabular}

${ }^{1} \mathrm{~V} / \mathrm{C}=$ Villus height $/$ Crypt depth

${ }^{2} \mathrm{CON}=$ nonchallenge control, $\mathrm{SCC}=$ Salmonella-challenged control, $\mathrm{O} 1=\mathrm{S}$. pullorum challenge fed the basal diet plus $50 \mathrm{mg} / \mathrm{kg} \mathrm{ORl} ; \mathrm{O} 2=S$. pullorum challenge fed the basal diet plus $80 \mathrm{mg} / \mathrm{kg} \mathrm{ORI}, \mathrm{O} 3=S$. pullorum challenge fed the basal diet plus $100 \mathrm{mg} / \mathrm{kg}$ ORI

${ }^{3} \mathrm{SEM}=$ standard error of mean

$4, a, b$ Values within a row not sharing the same superscript are different at $P<0.05 ; n=6$
Table 5 Effect of oridonin on the jejunal mucosa antioxidation function of broilers challenged with S. pullorum

\begin{tabular}{|c|c|c|c|c|c|c|c|}
\hline \multirow[t]{2}{*}{ Items } & \multicolumn{5}{|l|}{ Diet } & \multirow[t]{2}{*}{$\mathrm{SEM}^{2}$} & \multirow{2}{*}{$\begin{array}{l}P- \\
\text { value }\end{array}$} \\
\hline & CON & SCC & O1 & $\mathrm{O} 2$ & $\mathrm{O} 3$ & & \\
\hline \multicolumn{8}{|l|}{ Day 7} \\
\hline SOD (unit/mg prot) & 230 & 200 & 218 & 230 & 241 & 7.49 & 0.508 \\
\hline $\begin{array}{l}\text { MDA (nmol/mg } \\
\text { prot) }\end{array}$ & $0.23^{\mathrm{ab}}$ & $0.29^{a}$ & $0.22^{\mathrm{ab}}$ & $0.21^{\mathrm{ab}}$ & $0.19^{\mathrm{b}}$ & 0.01 & 0.019 \\
\hline \multicolumn{8}{|c|}{ Day 14} \\
\hline SOD (unit/mg prot) & $70^{\mathrm{a}}$ & $63^{b}$ & $64^{b}$ & $67^{\mathrm{ab}}$ & $78^{\mathrm{a}}$ & 1.67 & 0.021 \\
\hline $\begin{array}{l}\text { MDA (nmol/mg } \\
\text { prot) }\end{array}$ & 0.24 & 0.29 & 0.30 & 0.24 & 0.21 & 0.02 & 0.052 \\
\hline
\end{tabular}

Day 21

SOD (unit/mg prot) $184 \quad 144 \quad 147 \quad 164 \quad 171 \quad 6.16 \quad 0.125$

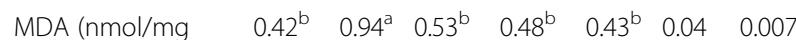
prot)

${ }^{1} \mathrm{CON}=$ nonchallenge control, $\mathrm{SCC}=$ Salmonella-challenged control, $\mathrm{O} 1=\mathrm{S}$. pullorum challenge fed the basal diet plus $50 \mathrm{mg} / \mathrm{kg} \mathrm{ORI} ; \mathrm{O} 2=S$. pullorum challenge fed the basal diet plus $80 \mathrm{mg} / \mathrm{kg} \mathrm{ORI}, \mathrm{O} 3=$ S. pullorum challenge fed the basal diet plus $100 \mathrm{mg} / \mathrm{kg}$ ORI

${ }^{2} \mathrm{SEM}=$ standard error of mean

$3, a, b, c$ Values within a row not sharing the same superscript are different at $P<0.05 ; \mathrm{n}=6$

mucosa at $21 \mathrm{~d}(P<0.05)$ compared with that of the SCC group. Compared with that of the SCC group, the MDA content in the jejunal mucosa of 7-d-old chicks did not decrease in the $\mathrm{O} 1$ or $\mathrm{O} 2$ group $(P>0.05)$, but it did decrease in the $\mathrm{O} 3$ group $(P<0.05)$. However, there were no differences in MDA content in the jejuna mucosa at 7 or $14 \mathrm{~d}$. The T-SOD activity in jejunal mucosa at $7 \mathrm{~d}$ or $21 \mathrm{~d}$ did not differ among groups $(P>0.05)$. The T-SOD activity in the SCC group decreased at $14 \mathrm{~d}(P<0.05)$ compared with that of $\mathrm{CON}(P<0.05)$. The incorporation of $100 \mathrm{mg} / \mathrm{kg}$ ORI increased T-SOD activity at $14 \mathrm{~d}$.

\section{$\lg A$ and $\lg G$ concentration}

Salmonella infection increased the concentrations of jejunal IgA and IgG at 7, 14, and $21 \mathrm{~d}(P<0.05)$ (Table 6). Dietary ORI decreased jejunum IgA and IgG contents at 7,14 , and $21 \mathrm{~d}(P<0.05)$ compared with those of the SCC $(P<0.05)$. However, there were no differences in the concentration of jejunal IgA or IgG between the CON and ORI group at 7,14 or $21 \mathrm{~d}(P>0.05)$.

\section{Discussion}

Salmonella infections resulting in slowed production performance, intestinal colonization, inflammation responses, and invasion of internal organs in broiler chickens have been reported [7]. In the present study, Salmonella infection had no effect on the production performance of the chicks, but certain short-term symptoms, such as reluctance to move, emotional panic, lethargy, lack of appetite, and decreased water intake 
Table 6 Effect of oridonin on IgG and IgA contents in jejunal mucosa of broilers challenged with S. pullorum

\begin{tabular}{|c|c|c|c|c|c|c|c|}
\hline \multirow[t]{2}{*}{ Items } & \multicolumn{5}{|l|}{ Diet } & \multirow[t]{2}{*}{$\mathrm{SEM}^{2}$} & \multirow{2}{*}{$\begin{array}{l}\text { P- } \\
\text { value }\end{array}$} \\
\hline & $\mathrm{CON}$ & SCC & O1 & $\mathrm{O} 2$ & $\mathrm{O} 3$ & & \\
\hline \multicolumn{8}{|l|}{ Day 7} \\
\hline lgG ( $\mu \mathrm{g} / \mathrm{mg}$ rot) & $1.64^{\mathrm{b}}$ & $2.62^{\mathrm{a}}$ & $2.07^{\mathrm{b}}$ & $1.97^{\mathrm{b}}$ & $1.85^{b}$ & 0.08 & 0.013 \\
\hline $\lg \mathrm{A}(\mu \mathrm{g} / \mathrm{mg}$ rot) & $2.43^{\mathrm{b}}$ & $4.17^{\mathrm{a}}$ & $3.87^{\mathrm{b}}$ & $2.77^{\mathrm{b}}$ & $2.48^{\mathrm{b}}$ & 0.14 & 0.021 \\
\hline \multicolumn{8}{|l|}{ Day 14} \\
\hline $\operatorname{lgG}(\mu \mathrm{g} / \mathrm{mg}$ rot) & $2.17^{b}$ & $4.28^{a}$ & $2.67^{b}$ & $2.41^{\mathrm{b}}$ & $2.19^{b}$ & 0.18 & 0.014 \\
\hline $\lg \mathrm{A}$ ( $\mu \mathrm{g} / \mathrm{mg}$ rot) & $2.24^{\mathrm{b}}$ & $4.05^{\mathrm{a}}$ & $3.76^{\mathrm{b}}$ & $2.42^{\mathrm{b}}$ & $2.21^{\mathrm{b}}$ & 0.22 & 0.011 \\
\hline \multicolumn{8}{|l|}{ Day 21} \\
\hline $\operatorname{lgG}(\mu \mathrm{g} / \mathrm{mg}$ prot $)$ & $2.42^{\mathrm{b}}$ & $5.07^{a}$ & $3.45^{\mathrm{b}}$ & $2.87^{\mathrm{b}}$ & $2.68^{\mathrm{b}}$ & 0.23 & 0.003 \\
\hline $\lg \mathrm{A}(\mu \mathrm{g} / \mathrm{mg}$ prot) & $2.05^{\mathrm{b}}$ & $2.41^{a}$ & $1.92^{\mathrm{b}}$ & $1.74^{\mathrm{b}}$ & $1.54^{\mathrm{b}}$ & 0.21 & 0.011 \\
\hline \multicolumn{8}{|c|}{$\begin{array}{l}{ }^{1} \mathrm{CON}=\text { nonchallenge control, } \mathrm{SCC}=\text { Salmonella-challenged control, } \mathrm{O} 1=\mathrm{S} . \\
\text { pullorum challenge fed the basal diet plus } 50 \mathrm{mg} / \mathrm{kg} \text { ORl; } \mathrm{O} 2=\mathrm{S} \text {. pullorum } \\
\text { challenge fed the basal diet plus } 80 \mathrm{mg} / \mathrm{kg} \mathrm{ORI}, \mathrm{O3}=\mathrm{S} \text {. pullorum challenge fed } \\
\text { the basal diet plus } 100 \mathrm{mg} / \mathrm{kg} \text { ORI } \\
{ }^{2} \mathrm{SEM}=\text { standard error of mean } \\
{ }_{3, \mathrm{a}, \mathrm{b}, \mathrm{c}, \mathrm{V} \text { Values within a row not sharing the same superscript are different at }} \\
P<0.05 ; \mathrm{n}=6\end{array}$} \\
\hline
\end{tabular}

appeared at $6 \mathrm{~d}$ of age, after the first inoculation. There were no apparent clinical symptoms at 11 or $18 \mathrm{~d}$. This finding is consistent with that of Chen et al. (2015), who noted that clinical symptoms vanished after operative treatment [8]. However, in some studies, the effects of salmonella were more severe likely due to age, bacterial serotype, dose or environmental conditions [3]. In any case, ORI did not show any effects on productive performance likely because of the lack of an effect of infection on such variables.

In previous studies, Salmonella caused a high level of infection in the caecum [9] and decreased the number of Lactobacillus colonies [10]. In the present study, the Salmonella count in SCC groups was higher than that of uninfected groups, whereas Salmonella inhibited the growth of Lactobacillus. Furthermore, Lactobacillus numbers markedly increased and Salmonella numbers decreased in the ORI treatment, with values similar to those of the control group. These results indicate that ORI can counteract Salmonella infection, promoting the growth of Lactobacilli to levels comparable to those in healthy chickens [11].

Villus height and crypt depth are important indices of the functional capacity of the enterocytes of broilers, and the $\mathrm{VH}: \mathrm{CD}$ ratio has been shown to immediately affect the digestion and absorption of the intestinal mucosa [12]. In the current study, nearly all measured morphometric parameters of the jejunum were affected after $4 \mathrm{~d}$ post infection. This finding agrees with the observation that Salmonella leads to apoptosis of cells in the jejunum [13]. Such processes tend to be attributed to the impairment of epithelial protein synthesis and function after Salmonella infection, which dramatically influence the early intestinal morphological development of chickens. As previously noted, dietary inclusion of ORI resulted in increased villus height and $\mathrm{VH}: \mathrm{CD}$ ratio and reduced crypt depth in broilers. The development of jejunal villi may be enhanced by the antibacterial and anti-inflammation properties of ORI.

Some studies have shown that intestinal oxidative stress and substantially impaired mucosal barriers occur in Salmonella challenged broilers [8]. The results of this study showed that Salmonella infection led to an imbalance of cytosolic redox status in favor of prooxidants, causing intestine cells to experience a state of oxidative stress in infected broilers. The results demonstrate that intestinal mucosal barriers were substantially disrupted in Salmonella challenged broilers. The molecular mechanisms of this mucosal barrier injury are completely unknown but may be due to the strong oxidative burst against Salmonella infection. However, administration of ORI to infected animals has maintained cellular antioxidant defense systems (T-SOD) at their normal levels, which might be due to a reduction in oxidant lesions by regulating the oxidation of T-SOD enzymes in the intestinal immune response.

The small intestine is one of the most important parts of the mucosal immunity system and provides antigen-specific protection by producing antibodies. Certain bacteria and viruses affect immunoglobulin synthesis, and Salmonella could induce marked intestinal immune responses characterized by the secretion of a large number of immunoglobulins in animals $[14,15]$. Thus, we investigated the effects of Salmonella challenge on immunoglobulins in the jejunum of broilers. The results verified that SCC chicks experienced increased concentrations of jejunal IgA and IgG in response to Salmonella intestinal infection.

IgA and IgG, the major immunoglobulins produced by lymphocytes of the mucosa, are clearly involved in the development of the intestinal immune response to Salmonella and are critical for protecting mucosal surfaces against toxins, viruses, and bacteria by neutralizing them or preventing them from binding to the mucosal surface [16-18]. In the present study, we found that ORI can decrease immunoglobulin concentrations (IgA and $\operatorname{IgG}$ ) in the jejunum. The mechanisms of ORI's immune-protecting properties may be partially attributed to $\mathrm{T}$ cell depletion in the peripheral immune system [19]. Additional studies will be required before the potential applications of ORI in feeding practices are fully understood.

\section{Conclusions}

In conclusion, our results suggest that $S$. pullorum can reduce the counts of Lactobacillus and the villi height of the small intestine and increase the counts of Salmonella, IgA concentrations in the jejunum, and the MDA content in the jejunum. ORI could protect the 
intestinal epithelium and normalize bacterial populations and immune response in Salmonella challenged broilers.

\section{Abbreviations}

BWG: Body weight gain; CON: Nonchallenge control; FCR: Feed conversion ratio; Fl: Feed intake; IgA: Immunoglobulin A; IgG: Immunoglobulin G; MDA: Malonaldehyde; ORI: Oridonin; SCC: Salmonella pullorum Challenged Control; T-SOD: Total superoxide dismutase

\section{Acknowledgments}

This study was supported by grants from the Foundation of State Key Laboratory of Animal Nutrition of China (2004DA125184f1407) and Nationa Natural Science Foundation of China (31470122). The authors thank their laboratory colleagues for their assistance.

\section{Funding}

Financial support for the study and its publication were provided by the Foundation of State Key Laboratory of Animal Nutrition of China (2004DA125184f1407) and National Natural Science Foundation of China (31470122). The State Key Laboratory of Animal Nutrition of China has given final approval of the version to be published.

\section{Availability of data and materials}

The datasets generated, used and analyzed during the current study are available from the corresponding author on reasonable request.

\section{Authors' contributions}

WQJ conceived the study, designed the methods, collected and transported data, performed the experimental and laboratory work, analyzed data, and drafted and finalized the manuscript for publication. ZXC participated in the design of the study and performed the statistical analysis. WT and ZTY conceived of the study, participated in its design and coordination, and helped to draft the manuscript. All authors read and approved the final manuscript.

\section{Ethics approval and consent to participate}

Principles of laboratory animal care were followed, and all procedures were conducted according to the guidelines of the Council for the International Organizations of Medical Sciences and the International Council for Laboratory Animal Science. All experimental procedures were approved by the Institutional Animal Care and Use Committee of the Nanjing Agricultural University (Nanjing, People's Republic of China).

\section{Consent for publication}

Not applicable.

\section{Competing interests}

The authors declare that they have no competing interests.

\section{Publisher's note}

Springer Nature remains neutral with regard to jurisdictional claims in published maps and institutional affiliations.

\begin{abstract}
Author details
'State Key Laboratory of Animal Nutrition, Institute of Animal Sciences of Chinese Academy of Agricultural Sciences, NO.2, Yuan Ming Yuan West Road, HaiDian District, Beijing 100193, People's Republic of China. ${ }^{2}$ College of Animal Science and Technology, Henan University of Science and Technology, No. 263, Kaiyuan Road, Luoyang 470003, Henan, People's Republic of China. ${ }^{3}$ College of Animal Science and Technology, Nanjing Agricultural University, No. 6, Tongwei Road, Xuanwu District, Nanjing 210095, Jiangsu, People's Republic of China.
\end{abstract}

Received: 24 January 2018 Accepted: 23 July 2018

Published online: 31 July 2018

\section{References}

1. Sato Y, Gihei S, Lawrence T, Pandey GS, Nakajima A, Chimana H, Henry S. Status of Salmonella gallinarum-pullorum Infections in Poultry in Zambia. Avian Dis. 41(2):490-5.
2. Barrow PA, Freitas NOC. Pullorum disease and fowl typhoid-new thoughts on old diseases: a review. Avian Pathol. 2011:40:1-13.

3. Wang $L C$, Zhang $T$, Wen $C$, Jiang ZY, Wang T, Zhou YM. Protective effects of zinc-bearing clinoptilolite on broilers challenged with Salmonella pullorum. Poultry Sci. 2012;91(8):1838-45.

4. Tian $\Pi$, Jin YR, Ma YH, Xie WW, Xu HJ, Zhang KR, Zhang LT, Du YF. Identification of metabolites of oridonin in rats with a single run on UPLC Triple-TOF-MS/MS system based on multiple mass defect filter data acquisition and multiple data processing techniques. J Chromatogr (B). 2015;1006:80-92.

5. Ming M, Sun FY, Zhang WT, Liu JK. Therapeutic effect of oridonin on mice with prostate cancer. Asian Pac J Trop Med. 2016;9(2):184-7.

6. Fujita E, Nagao Y, Kaneko K, Nakazawa S, Kuroda H. The antitumor and antibacterial activity of the Isodon diterpenoids. Chem Pharm Bull. 1976; 24(9):2118-27.

7. Chalghoumi R, Marcq C, Théwis A, Portetelle D, Beckers Y. Effects of feed supplementation with specific hen egg yolk antibody (immunoglobulin $Y$ ) on Salmonella species cecal colonization and growth performances of challenged broiler chickens. Poultry Sci. 2009;88:2081-92.

8. Chen GO, Sleman SMB, Mingan C, lji PA. Use of Lactobacillus Johnsonian in broilers challenged with Salmonella sofia. Anim Nutr. 2015;1:203-12.

9. Olnood CG, Beski SSM, Choct M, lji PA. Use of lactobacillus johnsonii in broilers challenged with Salmonella Sofia. Anim Nutr. 2015;1:203-12.

10. Carina AM, Oliver G, Apella MC. Protective effect of Enterococcus faecium J96, a potential probiotic strain, on chicken infected with Salmonella pullorum. J Food Prot. 2000:63:1333-7.

11. Zhao YJ, Lv H, Xu PB, Zhu MM, Liu Y, Miao CH, Zhu Y. Protective effects of oridonin on the sepsis in mice Kaohsiung. J Med Sci. 2016;32:452-7.

12. Rieger J, Janczyk P, Hünigen H, Neumann K, Plendl J. Intraepithelial lymphocyte numbers and histomorphological parameters in the porcine gut after enterococcus faecium NCIMB 10415 feeding in a Salmonella typhimurium challenge. Vet Immunol Immunopathol. 2015;164:40-50.

13. Zheng XC, Wu QJ, Song ZH, Zhang H, Zhang JF, Zhang LL, Zhang TY, Wang C, Wang T. Effects of Oridonin on growth performance and oxidative stress in broilers challenged with lipopolysaccharide. Poultry Sci. 2016;95(10):2281-9.

14. Methner U, Steinbach G. Efficacy of maternal Salmonella antibodies and experimental oral infection of chicks with Samonella enteritidis. Berl Munch Tierarztl Wochenschr. 1997;110:373-7.

15. Srikanth CV, Cherayil BJ. Intestinal innate immunity and the pathogenesis of Salmonella enteritis. Immunol Res. 1997;37:616.

16. Schroeder HW Jr, Cavacini L. Structure and function of immunoglobulins. J Allergy Clin Immun. 2010;125:S41-52.

17. Wieland WH, Orzaez D, Lammers A, Parmentier $H$, Verstegen $M$, Schots A. A functional polymeric immunoglobulin receptor in chicken (Gallus gallus) indicates ancient role of secretory $\lg \mathrm{A}$ in mucosal immunity. Biochem J. 2004:380:669-76.

18. Lammers A, Wieland WH, Kruijt L, Jansma A, Straetemans T, Schots A, Hartoga GD, Parmentier HK. Successive immunoglobulin and cytokine expression in the small intestine of juvenile chicken. Dev Comp Immunol. 2010:34:1254-62.

19. Guo WZ, Zheng PG, Zhang JK, Ming L, Zhou C, Zhang SJ. Oridonin suppresses transplant rejection by depleting $T$ cells from the periphery. Int Immunopharmacol. 2013;17:1148-54.

Ready to submit your research? Choose BMC and benefit from:

- fast, convenient online submission

- thorough peer review by experienced researchers in your field

- rapid publication on acceptance

- support for research data, including large and complex data types

- gold Open Access which fosters wider collaboration and increased citations

- maximum visibility for your research: over $100 \mathrm{M}$ website views per year

At BMC, research is always in progress.

Learn more biomedcentral.com/submissions 